\title{
A LEGALIDADE DA COBRANÇA DA TAXA DE FISCALIZAÇÃO DA AGÊNCIA NACIONAL DE TRANSPORTES TERRESTRES- ANTT ${ }^{1}$
}

THE LEGALITY OF CHARGING THE INSPECTION FEE OF THE AGÊNCIA NACIONAL DE TRANSPORTES TERRESTRES- ANTT

João Paulo Dias MORANDINI²

Silvio Marques GARCIA ${ }^{3}$

ISSUE DOI: $10.21207 / 2675-0104.2018 .800$

\begin{abstract}
RESUMO
A Agência Nacional de Transportes Terrestres- ANTT, em 19 de novembro de 2015, regulamentou, por meio da Resolução ANTT n. 4.936, os procedimentos para pagamento da taxa de fiscalização do serviço de transporte rodoviário coletivo interestadual e internacional de passageiros, cuja matéria é tratada no o art. 77, caput, inciso III, e $\S 3^{\circ}$, alterados pela Lei n. 12.996/2014, da Lei n. 10.233, de 5 de junho de 2001. A regulamentação da taxa de fiscalização deu origem a inúmeras demandas judiciais no país, as quais têm por finalidade obter a inexigibilidade dos créditos originários da referida resolução, com fundamento na sua ilegalidade e na afronta aos princípios da razoabilidade e proporcionalidade. As alegações dos que buscam judicialmente afastar a taxa também encontram espeque na afronta aos princípios tributários da capacidade contributiva e da vedação ao confisco.

Palavras-chave - Direito Tributário. Taxa. Taxa de fiscalização. ANTT. Princípio da vedação ao confisco.
\end{abstract}

\footnotetext{
${ }^{1} \mathrm{O}$ presente artigo sintetiza a monografia de conclusão da pesquisa, realizada para o Programa Interno de Bolsas de Iniciação Científica (PIBIC 2017-2018) da Faculdade de Direito de Franca (FDF), Franca/SP.

${ }^{2}$ Discente da Faculdade de Direito de Franca (FDF), Franca/SP. Bolsista do Programa Interno de Bolsas de Iniciação Científica (PIBIC 2017-2018).

${ }^{3}$ Doutorando em Direito (PUC/SP). Mestre em Direito (Unesp). Especialista em Direito Público (Unb/EAGU). Professor da Faculdade de Direito de Franca. Procurador Federal.
} 


\begin{abstract}
:
The general objective of the research is to elucidate the questions pertinent to the institution of the Inspection Fee, more specifically of the interstate and international collective road transport service of the Agência Nacional de Transportes Terrestres- ANTT. The mentioned autarchy, on November 19, 2015, regulated through the ANTT Resolution $n^{\circ} .4 .936$ the procedures for payment of the inspection fee for interstate and international passenger transport services, laid down in article 77, caput, III and $\S 3$ of Law $n^{\circ} 10,233$, of June 5, 2001, according to the text of Law 12,996/2014. The regulation of the inspection fee has motivated many judicial demands in the country aiming the non-enforceability of the credits originating from the aforementioned resolution. The principal allegation is a possible illegality and offense to the principle of reasonableness and proportionality and also a possible affront to the tax principle sealing to confiscation. The study elucidates and addresses some of the most important tax principles of the Brazilian legal system capable of elucidating the questions about the legality of the tax in analysis. In summary, through the exhibition and bibliographical analysis, as well as the understandings of the tribunals, we sought to outline the legal panoramas inherent to the referred tax, its impacts and relevant correlations to the current legal status. The study is extremely relevant in the economic sphere due to the context that the Brazilian State has faced and currently faces, especially considering the current tax burden and its impact on the road transport companies in the country, which has a fundamental role in Brazil's economy, development and good functioning, as showed by the recent shutdown of this sector.
\end{abstract}

Keywords: tax law. inspection fee. ANTT. Principle of sealing to confiscation

\title{
INTRODUÇÃO
}

Este artigo propõe-se analisar a regulamentação da taxa da ANTT de fiscalização do serviço de transporte rodoviário coletivo interestadual e internacional de passageiros, que deu origem a inúmeras demandas judiciais no país, pois dentre as alterações legais realizadas, instituiu-se o valor de $\mathrm{R} \$ 1800,00$ (um mil e oitocentos reais) por ano, cobrado de cada veículo da frota.

A regulamentação da taxa suscitou questionamentos acerca da sua legalidade, principalmente porque o valor anterior era de $\mathrm{R} \$ 200,00$ (duzentos reais) a título de registro e $\mathrm{R} \$ 10,00$ (dez reais) por veículo.

Diversas demandas surgiram com a finalidade de se obter a inexigibilidade dos créditos originários da resolução supracitada, com fulcro na sua possível ilegalidade ante a afronta a princípios tributários que baseiam o ordenamento jurídico pátrio. Tendo em vista o número expressivo de demandas judiciais envolvendo o tema em questão, merecem ser analisados os argumentos dos contribuintes de tal tributo.

A matéria em exame serve como base para a análise de outras taxas de fiscalização na medida em que, como se verá, são frequentemente oferecidos ao Poder Judiciário argumentos semelhantes em outros tributos desta espécie. Assim, este estudo possui relevância para além das fronteiras da taxa de fiscalização da Agência Nacional de Transportes Terrestres. 
Utilizando-se do método dedutivo, a pesquisa analisa o ordenamento tributário e verifica a adequação do regulamento da taxa de fiscalização aos princípios constitucionais tributários. Desse modo, o estudo enfoca pontos controvertidos e argumentos utilizados em demandas judiciais com a finalidade de examinar a exigibilidade do tributo em face dos princípios tributários.

\title{
2 PRINCÍPIOS TRIBUTÁRIOS REFERENTES À INSTIUIÇÃO DAS TAXAS
}

A análise dos princípios tributários é de grande valor no âmbito do estudo das taxas, uma vez que eles servem de fundamento jurídico para as ações que visam a afastar a cobrança do referido tributo. Acerca da delimitação da ideia geral dos princípios, Luiz Eduardo Schoueri esclarece:

\begin{abstract}
A ideia de "princípio" leva a "início", ou "base". Quando se buscam os princípios de uma ciência, pretende-se investigar se há, entre os elementos do objeto estudado, pontos em comum que lhe dão uma coesão. Identificados princípios comuns, pode-se desenvolver um ramo científico autônomo. ${ }^{4}$
\end{abstract}

Somente por meio da identificação dos princípios gerais e comuns de uma ciência é possível aplicá-los aos respectivos ramos científicos. Os princípios tributários sempre estarão apoiados em outros, de caráter mais geral, como o princípio da legalidade tributária (CF, art. 150, inc. I) em relação ao princípio da legalidade (geral) (art. $5^{\circ}$, inc. II).

Sobre a teleologia dos princípios, Luis Eduardo Schoueri continua:

[...] tanto princípios como regras pertencem à categoria deôntica. Diferem porque, enquanto as últimas descrevem imediatamente uma conduta, os primeiros apresentam um fim (estado ideal de coisas), a partir do qual se buscam os meios. Estes servem para a promoção do fim. (Grifos nossos)

Os princípios, a partir da influência de Ronald Dworkin ${ }^{5}$ e Robert $A l e x y^{6}$, foram elevados à categoria das normas e passaram a ser tratados como direito. Entende-se, dessa forma, que os princípios, assim como as

\footnotetext{
${ }^{4}$ SCHOUERI, Luiz Eduardo. Direito tributário. São Paulo: Saraiva, 2012. p. 323

${ }^{5}$ DWORKIN, Ronald. Levando os direitos a sério. 2. ed. São Paulo: Martins Fontes, 2007. passim.

${ }^{6}$ ALEXY, Robert. Teoria dos direitos fundamentais. 2. ed. São Paulo: Malheiros, 2012. passim.
} 
regras, são espécies de normas. Considerando-se os princípios constitucionais, é possível identificar as bases principiológicas que o legislador deve seguir na tarefa de regulamentação da atividade tributária. São funções da Constituição Federal definir, controlar e organizar o poder no Estado brasileiro. Aos princípios cabe orientar a instituição das regras e corrigir eventuais desvios e abusos de poder por parte da administração.

A Constituição Federal disciplinou o poder de tributar, impondolhe limites nos artigos 150, 151 e 152 . Assim, nasceram os mais variados princípios como por exemplo o princípio da legalidade tributária (art. 150, inc. I), o princípio da anterioridade tributária (art. 150, inc. III, alíneas a e b), princípio de vedação ao confisco (art. 150, inc. IV):

\footnotetext{
Art. 150. Sem prejuízo de outras garantias asseguradas ao contribuinte, é vedado à União, aos Estados, ao Distrito Federal e aos Municípios:

I - Exigir ou aumentar tributo sem lei que o estabeleça; [...]

III - cobrar tributos:

a) em relação a fatos geradores ocorridos antes do início da vigência da lei que os houver instituído ou aumentado;

b) no mesmo exercício financeiro em que haja sido publicada a lei que os instituiu ou aumentou; [...]

IV - Utilizar tributo com efeito de confisco; (Grifos nossos)
}

Eduardo Sabbag, acerca da instituição dos princípios tributários como forma de controle estatal, anota que:

\begin{abstract}
A Constituição Federal impõe limites ao poder de tributar, ou seja, limites à invasão patrimonial tendente à percepção estatal do tributo. Essas limitações advêm, basicamente, dos princípios e das imunidades constitucionais tributárias e estão inseridas nos arts. 150, 151 e 152 da Carta Magna. ${ }^{7}$
\end{abstract}

Os princípios, no direito brasileiro, são institutos que contêm o espírito do ordenamento. A análise das regras tributárias e dos requisitos objetivos que fundamentam o tributo será realizada em conjunto aos princípios tributários que regem a matéria.

Conseguir compreender a essência desses institutos é chegar próximo de um senso íntegro de justiça na medida em que isso possibilita a criação de balizas para a análise subjetiva dos casos concretos, tornando a tributação um ato, mais que legal, justo.

\footnotetext{
${ }^{7}$ SABBAG, Eduardo. Manual de direito tributário. São Paulo: Saraiva, 2016. p. 78
} 


\subsection{PRINCÍPIO DA LEGALIDADE}

O conceito de Estado Democrático de Direito está diretamente ligado ao princípio da legalidade, no qual predomina o chamado domínio da lei. Tal princípio ordena, grosso modo, que a relação entre os sujeitos de uma relação, públicos ou privados, se desenvolva a partir da confiança na atuação conforme a lei. Tal princípio existe para proteger as relações jurídicas de eventuais abusos e disfunções.

A melhor definição do princípio da legalidade (em geral) está contida, em apertada síntese, no inciso II, do artigo $5^{\circ}$ da Constituição Federal:

Art. $5^{\circ}$ Todos são iguais perante a lei, sem distinção de qualquer natureza, garantindo-se aos brasileiros e aos estrangeiros residentes no País a inviolabilidade do direito à vida, à liberdade, à igualdade, à segurança e à propriedade, nos termos seguintes: [...] II - ninguém será obrigado a fazer ou deixar de fazer alguma coisa senão em virtude de lei;

As principais funções do princípio da legalidade são: i) função garantidora de que os administrados só agirão ou deixarão de agir em face de norma instituída e, em complemento, ii) função limitadora do poder do Estado em sua relação com os administrados e como corolário garantir a segurança jurídica da sociedade. Sabe-se que o princípio em comento faz parte da base de todo ordenamento jurídico brasileiro e que as suas multifaces podem ser observadas em todos os ramos do direito.

$\mathrm{Na}$ seara das multifaces deste princípio, em relação ao Direito Penal, por exemplo, encontra-se o brocardo "Nullum crimen, nulla poena, sine praevia lege", que corresponde à ideia de inexistência de crime ou pena sem lei prévia. Pode-se observar que os atos da Administração Pública em regra geral, se forem produzidos sem base em legislação prévia, são por natureza nulos. Nesse brocardo, observa-se também a presença do princípio da anterioridade.

No Direito Administrativo, esse princípio atua como defesa dos administrados em face de possíveis arbitrariedades da Administração, exigindo-se que o Administrador demonstre o fundamento legal que autoriza e dá validade a seu ato. É nesse sentido a lição de Diógenes Gasparini:

O princípio da legalidade significa estar a Administração Pública, em toda a sua atividade, presa aos mandamentos da lei, deles não se podendo afastar. sob pena de invalidade do ato e 
responsabilidade de seu autor. Qualquer ação estatal sem o correspondente calço legal ou que exceda ao âmbito demarcado pela lei. É injurídica e expõe-se à anulação. ${ }^{8}$

Em relação ao Direito Tributário, o princípio da legalidade adquire características específicas, condensando-se em legalidade tributária (CF, art. 150, inc. I), mantendo-se, porém, como reflexo do artigo $5^{\circ}$, inc. II, da Carta Magna:

Art. 150. Sem prejuízo de outras garantias asseguradas ao contribuinte, é vedado à União, aos Estados, ao Distrito Federal e aos Municípios: I - exigir ou aumentar tributo sem lei que o estabeleça;

O Código Tributário Nacional também se ocupou do princípio da legalidade em seu "Art. 97. Somente a lei pode estabelecer: I - A instituição de tributos, ou a sua extinção;"

Os princípios no Direito podem ser enfocados sob diversos pontos de vista, dentre eles o filosófico, e não gozam da objetividade necessária à sua aplicação. Caberá à doutrina e à jurisprudência objetiválos e torná-los aptos à utilização nos casos concretos.

Uma das decorrências do princípio da legalidade no Direito Tributário diz respeito à impossibilidade de delegação legislativa. Sobre o tema, leciona Hugo de Brito Machado Segundo: ${ }^{9}$

Dizer que o tributo deve ser instituído por lei significa que esta deve
veicular todos os elementos da hipótese de incidência da norma
tributária (fato gerador, base imponível, sujeito ativo, sujeito
passivo, alíquota etc.). Não se admite, portanto, delegação da lei ao
ato normativo infralegal (v. g., regulamento), para que este último
defina aspectos essenciais da obrigação tributária e de sua gênese
[...]

Como se pode inferir da lição supra, a incidência da norma tributária deve levar em consideração elementos como o fato gerador, a base imponível, os sujeitos ativo e passivo, a alíquota, dentre outros, para que tal tributo seja instituído em conformidade com o ordenamento. A doutrina se preocupa em discriminar estes elementos e com isso cria marcos fundamentais à compreensão da legalidade do tributo e auxilia eventuais análises da sua razoabilidade e aplicabilidade.

\footnotetext{
${ }^{8}$ GASPARINI, Diógenes. Direito administrativo. $6{ }^{a}$ Ed. São Paulo: Saraiva, 2006. p.70.

${ }^{9}$ MACHADO SEGUNDO, Hugo de Brito. Código Tributário Nacional. São Paulo: Atlas, 2017. p. 46
} 


\subsection{DO SUJEITO PASSIVO DA RELAÇÃO TRIBUTÁRIA}

A regra matriz de incidência tributária disciplina as relações entre o Fisco e os contribuintes. Daí a relevância de se estudarem os seus diversos aspectos constitutivos inseridos na hipótese e no consequente. Relativamente às taxas de fiscalização, mostram-se relevantes os aspectos pessoal e quantitativo.

Partindo-se da análise dos elementos da incidência da norma tributária, é possível identificar na obrigação tributária o sujeito passivo.

O sujeito passivo, na relação tributária obrigacional, figura como o mais importante ente, na medida em que sobre ele recairá o encargo tributário e as responsabilidades dele oriundas. Acerca do sujeito passivo da relação tributária, conceitua o art. 121 e parágrafo único do CTN:

\footnotetext{
Art. 121. Sujeito passivo da obrigação principal é a pessoa obrigada ao pagamento de tributo ou penalidade pecuniária.

Parágrafo único. O sujeito passivo da obrigação principal diz-se:

I - Contribuinte, quando tenha relação pessoal e direta com a situação que constitua o respectivo fato gerador;
}

A coerção do patrimônio do particular, inserido na relação tributária como sujeito passivo, depende da identificação da possibilidade econômica e jurídica de ser realizar a cobrança. Necessário, neste ponto, analisar o princípio da capacidade contributiva do sujeito passivo, relacionando-o à instituição das taxas.

Com relação ao quantum debeatur, a fixação do montante devido não pode levar em consideração apenas circunstâncias relacionadas ao sujeito passivo ou seus bens. Nesse sentido é a lição de Hector Villegas, citado por Geraldo Ataliba:

A taxa também tem limites que são naturais à sua própria conformação subjetiva e que estão referidos ao seu montante. Estes limites devem partir da noção básica, segundo a qual a mesma é um tributo vinculado, sendo sua hipótese de incidência uma determinada atividade estatal suscetível de ser individualizada, relativamente a determinada pessoa. Daí por que a fixação do montante não poder levar em conta circunstâncias inerentes à pessoa ou aos bens do obrigado (que são hipótese de incidência de imposto), mas só circunstâncias atinentes à atividade em si mesma, 
por ser ela, e não outra coisa, a hipótese de incidência da obrigação correspondente às taxas. ${ }^{10}$

Por isso, tendo em vista o atributo da taxa de constituir receita para a autarquia fiscalizadora, a majoração do tributo deve observar diversos elementos e não somente aspectos relacionados ao contribuinte. Do contrário, a manutenção de um valor baixo para a citada taxa exigiria complementação da receita da autarquia por meio da destinação de recursos provenientes dos impostos, tributos que têm por natureza a desvinculação da receita, o que acarretaria uma sobrecarga para os contribuintes em geral e não apenas para os empresários do setor, isto é, aqueles que lucram com a atividade e, por essa razão, devem suportar seus custos.

\subsection{DA CAPACIDADE CONTRIBUTIVA}

O princípio tributário da capacidade contributiva, em apertada síntese, visa a balizar a instituição/criação de um novo tributo levando à aplicação os conceitos de igualdade material na cobrança realizada pela Administração Pública.

Acerca do mencionado princípio, leciona Regina Helena Costa:

A capacidade contributiva pode ser: (i) um limite ou critério para a graduação da tributação; ou (ii) um parâmetro para a distinção entre situações tributáveis e não tributáveis. No primeiro caso, falar-se-á em capacidade contributiva relativa ou subjetiva; no último, em capacidade contributiva absoluta ou objetiva ${ }^{11}$.

\section{Para Luiz Eduardo Schoueri:}

A questão se resume a saber se existe um ponto, abaixo ou acima do qual descabe a incidência de um tributo, ou, ainda, até onde pode atingir a tributação; no primeiro caso, estar-se-á cogitando do mínimo de subsistência; ultrapassado o limite, versar-se-á sobre o confisco. $^{12}$

\footnotetext{
${ }^{10}$ VILLEGAS, Hector. Verdades e ficções em torno do tributo denominado taxa. RDP, n. 17, p. 337, apud ATALIBA, Gerado. Hipótese de incidência tributária. 6. ed. São Paulo: Malheiros, 2014. p. 111.

${ }^{11}$ COSTA, Regina Helena. Princípio da capacidade contributiva. 2. ed. São Paulo: Malheiros, 1996. p. 29.

${ }^{12}$ SCHOUERI, Luiz Eduardo. Direito Tributário. São Paulo: Saraiva, 2002. p. 380
} 
No caso da taxa de fiscalização da ANTT, instituiu-se o valor de $\mathrm{R} \$ 1800,00$ (um mil e oitocentos reais) por ano e por veículo da frota. Os argumentos que lastreiam a possível ilegalidade do tributo estão pautados na definição legal da prestação pecuniária compulsória a todos os taxados sem realizar distinção ou qualquer diferenciação entre as empresas, maiores e menores, atuantes no setor de transporte.

As ações que visam a suspender a referida taxa geralmente são fundamentadas no artigo 179 da Constituição Federal:

\footnotetext{
Art. 179. A União, os Estados, o Distrito Federal e os Municípios dispensarão às microempresas e às empresas de pequeno porte, assim definidas em lei, tratamento jurídico diferenciado, visando a incentivá-las pela simplificação de suas obrigações administrativas, tributárias, previdenciárias e creditícias, ou pela eliminação ou redução destas por meio de lei
}

A Lei Maior determina que deverão existir condições especiais às microempresas e empresas de pequeno porte por meio de tratamento jurídico diferenciado, simplificando suas obrigações tributárias. A interpretação acerca do conteúdo da proteção tem levado à análise do Poder Judiciário muitas taxas de fiscalização em razão das incertezas resultantes desse denominado tratamento diferenciado.

Em tais demandas, é comum confundir-se, de certa forma, o tratamento diferenciado com o dever/obrigação que cabe à Administração Pública de fornecer os seus serviços a título gratuito em face do montante de lucro inferior que as empresas auferem, se comparadas às que dominam o setor. Como se sabe, a imunidade tributária depende de expressa previsão constitucional e isenção, de expressa previsão legal.

Buscando forçar a concessão certa benesse ou gradação tributária, cobra-se do Poder Judiciário a interferência nos atos do Poder Legislativo. Em consequência, poderá haver invasão de competência, sob a alegação de realizar-se tratamento diferenciado, mesmo inexistindo regulamentação legal.

Noutro giro, para a efetivação da previsão constitucional de tratamento diferenciado às empresas menores, a Administração Pública federal instituiu o regime tributário conhecido como "SIMPLES" nacional, regulamentado na Lei Federal n. 9.317/96 e na LC 123/2006, que elenca, dentre outros pontos, quais tributos serão recolhidos de forma especial nesse regime. Não obstante, cabe notar que não consta, nos referidos diplomas legais, a possibilidade de simplificação tributária referente às taxas de fiscalização. 
Em caso análogo, mais especificamente quanto à taxa de fiscalização do Instituto Brasileiro do Meio Ambiente e dos Recursos Naturais Renováveis- IBAMA o Superior Tribunal de Justiça- STJ decidiu:

PROCESSUAL CIVIL E TRIBUTÁRIO. AÇÃO ANULATÓRIA. TAXA DE CONTROLE E FISCALIZAÇÃO AMBIENTAL TCFA. NATUREZA JURÍDICA DA EXAÇÃO QUESTIONADA DEFINIDA PELO STF, POR OCASIÃO DO JULGAMENTO DO RE 416.601/DF. INCLUSÃO DA TAXA REFERIDA NA SISTEMÁTICA DE ARRECADAÇÃO SIMPLIFICADA (SIMPLES). DESCABIMENTO. AUSÊNCIA DE PREVISÃO NAS LEIS 9.317/96 E LC 123/2006. 1. Discute-se no recurso especial a possibilidade de inclusão da Taxa de Controle e Fiscalização Ambiental -TCFA, instituída pela Lei 6.938/81, alterada pela Lei $10.165 / 2000$, destinada ao IBAMA no Sistema Integrado de Recolhimento de Tributos - SIMPLES. 2. O STF, no que diz respeito à natureza jurídica da Taxa de Controle e Fiscalização Ambiental - TCFA, instituída pela Lei 10.165/2000, que alterou a Lei $6.938 / 1981$, por ocasião do julgamento do RE 416.601/DF, decidiu que a hipótese de incidência da taxa em destaque decorre da fiscalização de atividades poluidoras e utilizadoras de recursos ambientais, ou seja, remunera o exercício do poder de polícia do Estado exercido pelo IBAMA. 3. A forma simplificada de tributação (SIMPLES) engloba o recolhimento exclusivo de tributos e contribuições expressamente elencados na Lei 9.317/96 e LC 123/2006. Não se revela possível abranger no sistema de arrecadação diferenciado, por ausência de previsão legal, a Taxa de Controle e Fiscalização Ambiental -TCFA, cuja finalidade específica decorre do poder fiscalizador do IBAMA, em face da previsão contida no art. 145, II, da Constituição Federal de 1988, conforme já decidiu o STF no julgamento do RE 416.601/DF. 4. Recurso especial provido. (REsp 1242940/PR, Rel. Primeira Turma, Rel. Min. Benedito Gonçalves, DJe de 26/10/2012).

Da análise da decisão supra, resta clara a impossibilidade de o Poder Judiciário alterar o valor das taxas ou a sua forma de pagamento, sob o argumento da existência de tratamento diferenciado às empresas em razão de seu tamanho. Tal tratamento é realizado por meio de outras medidas, como o SIMPLES nacional, não devendo ser invocado em casos isolados.

Sobre a taxa em estudo, cumpre destacar o julgado:

AGRAVO DE INSTRUMENTO. AÇÃO DECLARATÓRIA. PROBABILIDADE DO DIREITO. 1. A Lei No 10.233/01 (art. 77, inc. III e $\S 3^{\circ}$ ) estabelece que a ANTT deverá cobrar a Taxa de Fiscalização, indistintamente, no valor de R\$ 1.800,00 (mil e oitocentos reais), por ano e por ônibus registrado, no caso do transporte rodoviário coletivo interestadual e internacional de 
passageiros. 2. Não soa razoável a declaração da violação dos princípios da isonomia e da capacidade contributiva, ainda mais que a taxa em questão é cobrada por ônibus registrado. Logo, a empresa que possuir maior frota, logicamente, terá maior aporte de recursos para de desincumbir de sua obrigação legal. 3. Agravo provido para reformar a decisão que suspendeu a exigibilidade da taxa. (TRF4, AG 5041440-77.2016.404.0000, SEGUNDA TURMA, Relator OTÁVIO ROBERTO PAMPLONA, juntado aos autos em 06/12/2016)

A relação da taxa com o princípio da proporcionalidade e o favorecimento das empresas menores é facilmente reconhecida quando a lei define o valor, mesmo sendo fixo, que sobre cada veículo da frota incidirá a taxa de fiscalização.

Dessa forma, o tratamento diferenciado às micro e pequenas empresas é respeitado. Não é necessário intervenção judiciária nas disposições do programa SIMPLES nacional, na medida em que a proporcionalidade tributária atende à capacidade contributiva do contribuinte e, portanto, à legalidade da taxa.

\subsection{PRINCÍPIO TRIBUTÁRIO DA VEDAÇÃO AO CONFISCO}

Outro princípio relacionado ao sujeito passivo é o da vedação ao confisco, insculpido no artigo 150, IV da Constituição Federal:

Art. 150. Sem prejuízo de outras garantias asseguradas ao contribuinte, é vedado à União, aos Estados, ao Distrito Federal e aos Municípios: [...] IV - Utilizar tributo com efeito de confisco.

O confisco, do latim confiscare é o ato de restringir o patrimônio particular em benefício do Fisco. O confisco tem caráter de penalidade e decorre da prática de algum ato contrário à lei.

Tributo e confisco são conceitos antagônicos. Por um lado, o Tributo tem dicção expressa no art. $3^{\circ}$ do Código Tributário Nacional, que o define, como prestação compulsória que não seja ato ilícito:

Art. $3^{\circ}$ Tributo é toda prestação pecuniária compulsória, em moeda ou cujo valor nela se possa exprimir, que não constitua sanção de ato ilícito, instituída em lei e cobrada mediante atividade administrativa plenamente vinculada. 
De outro lado, o confisco está associado invariavelmente à noção de sanção. A Constituição Federal prevê a perda de bens como forma de punição de caráter penal $\left(\mathrm{CF}\right.$, art. $5^{\circ}$, inc. XLVI, alínea $\left.b\right)$.

Fábio Brun Goldschmidt relaciona os conceitos de tributo e confisco: "Os dois conceitos aproximam-se, contudo, quando se pretende examinar a medida aceitável, razoável da tributação." ${ }^{13}$ Sobre o assunto, Aliomar Baleeiro esclarece que, "[t]ecnicamente, tributo e confisco não se confundem, mas o que no art. 150 , IV, se veda é que a lei regule o tributo de modo que ele gere os mesmos efeitos econômicos que o confisco geraria"14

Acerca do princípio da relação do princípio em comento com as taxas, Goldschmidt acrescenta que:

A Taxa, instituída com base no poder de polícia, que extravasa os limites quantitativos autorizadores de sua cobrança, indubitavelmente colide com o art. 150, IV, da Constituição, da mesmíssima forma que a taxa instituída como contraprestação ao serviço público gera efeito de confisco quando ultrapassa o valor desses serviços ${ }^{15}$

O princípio da vedação ao confisco tem sido outro fundamento invocado em defesa dos que buscam na via judicial a inexigibilidade do tributo. Porém, a invocação do princípio não atenta para ideia de que os princípios balizam o ramo do Direito Tributário de forma geral, não se preocupando em atingir, na maioria das vezes, situações específicas.

Aplicar princípios a situações isoladas pode gerar excessiva desproporcionalidade jurídica entre a administração e os administrados. Exempli gratia, suponha-se que em um determinado mês o contribuinte fique desempregado. A capacidade contributiva desse sujeito passivo reduzir-se-á, a menos que ele tenha outras fontes de renda, a zero. Com tal argumento, esse contribuinte poderia ajuizar diversas demandas com o propósito de não pagar seus débitos tributários, utilizando argumentos como o princípio da capacidade contributiva e a vedação ao confisco.

Em diversas ações, a intenção do contribuinte é suspender a exigibilidade de tributos como meio de desonerar-se de certas obrigações, que poderiam ser facilmente suportadas por ele.

\footnotetext{
${ }^{13}$ GOLDSCHMIDT, Fábio Brun. O Princípio do não-confisco no direito tributário. São Paulo: Ed. Revista dos Tribunais, 2003. p. 48.

${ }^{14}$ BALEEIRO, Aliomar. Limitações constitucionais ao poder de tributar. 7. ed. Rio de Janeiro: Forense, 1997. p. 573.

${ }^{15}$ GOLDSCHMIDT, Fábio Brun. O Princípio do não-confisco no direito tributário. São Paulo: Ed. Revista dos tribunais, 2003. p. 262.
} 
É oportuno o comentário de Hugo de Brito Machado Segundo acerca do efeito confiscatório:

Confisco e carga tributária total - O efeito confiscatório do tributo não deve ser avaliado através de um exame da carga tributária representada por cada tributo, isoladamente, mas pelo somatório de todos os tributos que oneram uma mesma realidade ${ }^{16}$.

Em síntese, o argumento do efeito confiscatório também não afasta a instituição do tributo em razão do número de veículos da frota. É muito provável que o próprio veículo taxado, utilizado no desempenho das funções da empresa, produza a receita necessária ao cumprimento das obrigações tributárias para com a autarquia reguladora.

\section{CARÁTER ARRECADATÓRIO DA TAXA}

É patente que o serviço de fiscalização disponibilizado pela autarquia gera custos à Administração Pública, na medida em que se faz possível a partir de investimentos na área. Em razão de o serviço ser utilizado apenas pelo setor, não seria justo transferir tal encargo à sociedade como um todo. Ademais, a empresa deve arcar com os custos e riscos do negócio. Nesse sentido, o instituto da taxa foi criado como espécie de tributo contraprestacional em que o administrado devolve ou antecipa ao Estado os custos que sua atividade gera.

A respeito da taxa de fiscalização da ANTT e da ANTAQ, o art. 77, inc. III, da Lei n. 10.233/2001, alterada pela Lei n. 12.996/2014, dispõe:

Art. 77. Constituem receitas da ANTT e da ANTAQ: [...] III - os produtos das arrecadações de taxas de fiscalização da prestação de serviços e de exploração de infraestrutura atribuídas a cada Agência.

Como se pode depreender do diploma legal estudado, o tributo em questão não se restringe a antecipar/repor as verbas utilizadas pela administração na prestação de serviços fiscalizatórios, mas também exerce a função de captar receitas para a autarquia.

Sobre este fator, muitas são as críticas em razão da possibilidade de o tributo ser utilizado de maneira meramente arrecadatória. Salienta-se

${ }^{16}$ MACHADO SEGUNDO, Hugo de Brito. Código Tributário Nacional. São Paulo: Atlas, 2017. p. 58. 
a crítica social presente no cotidiano dos brasileiros referentes à chamada "indústria da multa". É sabido que as multas de trânsito são uma forma de a Administração Pública controlar a segurança no trânsito.

O que se observa é o número exagerado na aplicação destas sanções em relação à notória falta de repasse de receitas aos órgãos fiscalizadores. Diante dessa realidade, os administrados muitas vezes questionam a instituição de taxas que possam ter caráter meramente arrecadatório.

A Procuradoria-Geral Federal defendeu, na ação ordinária n. 25301-59.2016.4.01.3900, a legalidade da cobrança da taxa como forma de manter o custeio das atribuições inerentes ao exercício do poder de polícia nas atividades de fiscalização.

\section{A CONSTITUCIONALIZAÇÃO DO DIREITO ADMINISTRATIVO E O CONTROLE JUDICIAL DO MÉRITO DO ATO ADMINISTRATIVO}

É patente no sistema de justiça brasileiro o fenômeno denominado "judicialização". Em apertada síntese, esse fenômeno se dá por meio da provocação da atividade jurisdicional como meio de solução de conflitos a que os demais poderes, Executivo e Legislativo, não conseguem oferecer solução.

O ativismo judicial é assim conceituado por Luís Roberto Barroso:

O ativismo judicial é uma atitude, a escolha de um modo específico e proativo de interpretar a Constituição, expandindo o seu sentido e alcance. Normalmente ele se instala em situações de retração do Poder Legislativo, de um certo descolamento entre a classe política e a sociedade civil, impedindo que as demandas sociais sejam atendidas de maneira efetiva ${ }^{17}$

Do excerto supramencionado podemos observar que o ativismo judicial habita no distanciamento entre o Poder Legislativo e a população. Muitas vezes distanciado da realidade social e atendendo a outros interesses, o Legislativo por vezes contraria uma das máximas que

\footnotetext{
${ }^{17}$ BARROSO, Luís Roberto. Judicialização, ativismo judicial e legitimidade democrática. Brasília, 02/02/2009.Disponívelem:<https://www.direitofranca.br/direitonovo/FKCEimagens/file/ArtigoBarro so_para_Selecao.pdf $>$. Acesso em: 18 jul. 2018.
} 
disciplinam o ordenamento jurídico romano-germânico: Ubi Societas, Ibi $J u s$, que traduzido, se define em "Onde está a sociedade, está o Direito".

Trata-se a judicialização de um fenômeno mundial que encontra peculiaridades na Constituição de 1988. Insere-se em uma espécie de linha tênue entre a perfeita harmonia dos três poderes e a interferência indevida ou desmedida do Poder Judiciário, por meio do ativismo judicial, no sistema de freios e contrapesos político brasileiro. Na medida em que o descontentamento da população brasileira cresce e a confiança na administração pública sucumbe, é no Poder Judiciário que se concentra a confiança na justiça do país. A judicialização, entretanto, não tem trazido ao Judiciário prestígio maior do que os demais poderes. A prestação judicial não se tornou efetiva e, ademais, com a interferência no âmbito político-administrativo, o próprio Judiciário tem sido alvo de críticas e insatisfação da opinião pública.

Levando em consideração os conceitos apresentados e considerando ainda as diretrizes do Direito Administrativo, cabe analisar a possibilidade de controle judicial do mérito administrativo.

Pelo princípio da legalidade, contido no art. 37 da Constituição Federal, a Administração Pública deve praticar atos balizando-se nos diplomas legais que regulamentam sua atuação. O poder discricionário, em apertada síntese, permite ao administrador praticar atos com certa margem de liberdade apresentando a solução que melhor atenda à satisfação do interesse público.

Em razão do poder discricionário, surgem inúmeros questionamentos acerca da legalidade do mérito do ato administrativo. A crescente constitucionalização dos direitos teve como consequência o questionamento judicial dos atos discricionários. Sobre essa questão, disserta Fernandes:

\footnotetext{
Mais recentemente, tem-se verificado uma ampliação ainda maior do controle judicial dos atos administrativos com base numa releitura daqueles mesmos princípios, acarretando uma redução tão significativa na discricionariedade administrativa que muitos doutrinadores vêm sustentando que já não subsiste mais o conceito de mérito administrativo como limite ao controle judicial dos atos $\operatorname{administrativos}^{18}$
}

\footnotetext{
${ }^{18}$ FERNANDES, André Dias. A constitucionalização do Direito Administrativo e o controle judicial do mérito do ato administrativo. Revista de Informação Legislativa, Brasília, ano 51, n. 203, p. 143164, jul./ set. 2014.
} 
Assim, o Poder judiciário, instado a manifestar-se sobre o mérito dos atos administrativos, muitas vezes suspende atos com fundamento na suposta dissonância entre os motivos do administrador e os princípios constitucionais que disciplinam a efetivação dos direitos. Acerca da análise do mérito, continua Fernandes:

\footnotetext{
Por outro lado, a denominada constitucionalização do direito administrativo é o fator que mais tem contribuído para a redução da discricionariedade e do mérito administrativo. [...] Com efeito, só depois de uma análise global, completa e irrestrita de todos os aspectos do ato administrativo (inclusivamente a conveniência e a oportunidade) é que o juiz pode afirmar se o ato é, ou não é, razoável e proporcional, e, por conseguinte, o que pode e o que não pode modificar no ato administrativo. Todavia, numa acepção mais restrita e literal, "apreciar" um ato administrativo não é o mesmo que "anular" esse ato. Da "apreciação" do ato administrativo pode resultar, ou não, a sua "anulação": a anulação do ato é uma possível consequência da atividade de "apreciação". ${ }^{19}$
}

A possibilidade de anulação de um ato da administração pública somente poderia se dar após a análise minuciosa dos motivos que culminaram com a edição daquele ato. Não cabe expandir o entendimento e aplicabilidade dos princípios constitucionais com o intuito de anular todos os atos que a administração pública pratica, em sede de poder discricionário ou não.

O que se observa é o descontentamento da população em face do poder público convergindo em um número exagerado de demandas judiciais sob o argumento de que uma determinada lei ou ato administrativo fere os princípios da legalidade, razoabilidade ou proporcionalidade.

Instado a resolver os conflitos que lhe são oferecidos, o Poder Judiciário, utilizando-se de ativismo judicial, frequentemente invade a competência administrativa ou legislativa e anula atos sem analisar o universo de elementos que culminaram na tomada de decisão.

O caso da taxa em estudo não é diferente, uma vez que Associação Brasileira das empresas de Transporte de Passageiros (ABRATI) obteve em caráter liminar a suspensão da taxa de fiscalização da ANTT invocando a quebra dos princípios já estudados.

Em síntese, conclui-se que, por mais que a taxa tenha sofrido majoração, ou que o aumento seja considerado elevado, a via eleita para a discussão deve ser diretamente com os agentes públicos competentes, os

\footnotetext{
${ }^{19}$ Ibidem.
} 
deputados e senadores, sob pena de patente desequilíbrio entres poderes Executivo, Legislativo e Judiciário.

Relativamente ao tema ora discutido, cumpre mencionar o Projeto de Lei n. 4.864/2016, que visa a diminuir o valor do referido tributo.

\subsection{PROJETO DE LEI N. 4.864/2016}

Ante a indignação em face do valor cobrado a título de taxa de fiscalização da ANTT, o Deputado Diego Andrade, do Partido Social Democrático (PSD), propôs o Projeto de Lei n. 4.864/16, o qual visa a alterar a redação do parágrafo $3^{\circ}$ do art. 77 da Lei n. 10.233/2001, dandolhe a seguinte redação:

$\S 3^{\circ}$ No caso do transporte rodoviário coletivo interestadual e internacional de passageiros, a taxa de fiscalização de que trata o inciso III do caput deste artigo não poderá ultrapassar o valor de R \$ 200,00 (duzentos reais) por ano e por ônibus registrado pela empresa detentora de autorização ou permissão outorgada pela ANTT." (NR)

Como é praxe na propositura de projeto de lei, a justificativa do Deputado assim expõe a questão:

Este projeto de lei tem como objetivo tornar a Taxa de Fiscalização, prevista na Lei $\mathrm{n}^{\circ} 10.233$, de junho de 2001, razoavelmente praticável aos empreendedores do sistema rodoviário coletivo interestadual e internacional. Atualmente essa taxa possui o valor de $\mathrm{R} \$ 1.800,00$. Trata-se de um valor abusivo se considerar que a Agência Nacional de Transporte Terrestre - ANTT possui, entre outras fontes de receitas, recursos do Orçamento Geral da União para desenvolver suas atividades precípuas. Essa cobrança onera abusivamente toda a atividade de transporte rodoviário interestadual e internacional de passageiros, mas principalmente os transportadores autônomos, parcela economicamente mais fraca dessa atividade.É de extrema importância que o poder público possua recursos para realizar a fiscalização, bem como honrar com as despesas de custeio da máquina pública. Assim sendo, é aceitável e economicamente viável que essa taxa possua um valor suportável pelos empresários desse seguimento de transporte, sem, contudo, caracterizar abusividade governamental. A manutenção do valor de $R \$ 1.800,00$ da taxa de fiscalização demonstra completa falta de correspondência entre o valor tributário exigido e o custo da atividade estatal, sendo de extrema necessidade reaver o atual valor dessa taxa. Desse modo, com o objetivo de evitarmos a abusividade do poder público em tributar o cidadão que gera 
emprego e renda, conto com o apoio dos nobres pares pela aprovação desta proposição. (Grifos nossos).

Diferentemente das tutelas concedidas pelo Judiciário, o legislativo discutirá a proposta e realizará minucioso estudo acerca da necessidade ou não de diminuição da taxa e das suas consequências. Notase que o deputado oportuniza a citação de alguns princípios tributários para defender a necessidade da alteração legislativa. Porém, utiliza-os corretamente, abrindo margem à discussão de todo o universo tributário relacionado à exação.

O projeto de lei em questão foi aprovado por unanimidade pela Comissão de Viação e Transportes (CVT) e atualmente está em análise pela Comissão de Finanças e Tributação (CFT).

\section{CONSIDERAÇÕES FINAIS}

O intuito deste estudo foi analisar a legalidade da Taxa de Fiscalização da ANTT. O princípio da legalidade é amplamente debatido em relação aos mais diversos temas no direito brasileiro. Com relação às regras que dizem respeito à cobrança de tributos, dentre eles as taxas de fiscalização, não é diferente.

A análise da legalidade do tributo em questão foi realizada a partir dos elementos constitutivos da obrigação tributária, tais como o fato gerador, a base de cálculo e o sujeito passivo. Definiram-se as suas relações com os princípios tributários que regem a imposição tributária.

A taxa institui valor único a todos os contribuintes, porém, esta premissa não é suficiente a configurar quebra do princípio da capacidade contributiva, uma vez que, em razão da disciplina da incidência da taxa sobre cada veículo da frota, a referida taxa atende à proporcionalidade. Ademais, respeita a capacidade contributiva dos sujeitos passivos e também não está presente o efeito confiscatório.

No que toca à majoração da taxa de fiscalização da ANTT, foi analisada a hipótese de quebra ao princípio da razoabilidade em razão do valor significativamente inferior cobrado anteriormente. De início, a majoração não pareceu adequada. Entretanto, na medida em que o serviço de fiscalização havia sido regulamentado há tempos, vários foram os fatores justificantes dessa majoração. Cabe ainda mencionar que, dividindo-se o valor dessa taxa durante o exercício a que se refere, não 
apresenta valores estratosféricos, se comparada aos benefícios que a regular fiscalização traz para o setor.

Em relação aos requisitos legais necessários à instituição da referida taxa, não houve falha no processo de elaboração legislativa. De outro lado, a taxa em questão observou o princípio da legalidade tributária no tocante a existência de lei anterior que a institui.

Dado o atributo da taxa de constituir receita para a autarquia fiscalizadora, a majoração do tributo deve observar diversos elementos e não somente aspectos relacionados ao contribuinte. Do contrário, a manutenção de um valor baixo para a citada taxa exigiria complementação da receita da autarquia por meio da destinação de recursos provenientes dos impostos, tributos que têm por natureza a desvinculação da receita, o que acarretaria uma sobrecarga para os contribuintes em geral e não apenas para os empresários do setor, isto é, aqueles que lucram com a atividade e, por essa razão, devem suportar seus custos.

Dessa forma, por não terem sido observadas disfunções legais, afronta a qualquer princípio constitucional ou tributário, as razões que levaram à majoração da taxa de fiscalização da ANTT observaram o princípio da legalidade, conformidade essa já reconhecida em alguns julgados, como se verificou neste estudo. A relevância da análise desse tema poderá projetar-se sobre as taxas de fiscalização cobradas por outras autarquias, que por razões semelhantes possam ser majoradas de forma análoga.

\section{REFERÊNCIAS BIBLIOGRÁFICAS}

ALEXY, Robert. Teoria dos direitos fundamentais. 2. ed. São Paulo: Malheiros, 2012.

ATALIBA, Gerado. Hipótese de incidência tributária. 6. ed. São Paulo: Malheiros, 2014.

BALEEIRO, Aliomar. Limitações constitucionais ao poder de tributar. 7. ed. Rio de Janeiro: Forense, 1997.

BARROSO, Luís Roberto. Judicialização, ativismo judicial e legitimidade democrática. Brasília, 2 fev. 2009. Disponível em:

〈https://www.direitofranca.br/direitonovo/FKCEimagens/file/ArtigoBarroso_para_Selecao.pdf>. Acesso em: 18 jul. 2018

COSTA, Regina Helena. Princípio da capacidade contributiva. 2. ed. São Paulo: Malheiros, 1996.

DWORKIN, Ronald. Levando os direitos a sério. 2. ed. São Paulo: Martins Fontes, 2007. 
FERNANDES, André Dias. A constitucionalização do Direito Administrativo e o controle judicial do mérito do ato administrativo. Revista de Informação Legislativa, Brasília, ano 51, n. 203, p. 143 164, jul./ set. 2014.

GASPARINI, Diógenes. Direito administrativo. 6ª ed. São Paulo: Saraiva, 2006.

GOLDSCHMIDT, Fábio Brun. O Princípio do não-confisco no direito tributário. São Paulo: Ed. Revista dos Tribunais, 2003.

MACHADO SEGUNDO, Hugo de Brito. Código Tributário Nacional. São Paulo: Atlas, 2017.

SABBAG, Eduardo. Manual de direito tributário. São Paulo: Saraiva, 2016.

SCHOUERI, Luiz Eduardo. Direito tributário. São Paulo: Saraiva, 2012. 